\title{
Luz(es) del Fuego: rebeldia e feminismos*
}

\section{Karla Bessa*}

\begin{abstract}
Resumo
O artigo apresenta uma leitura do filme Luz Del Fuego, de David Neves, (1982) a partir de uma abordagem feminista, que interliga análise histórica e análise fílmica. Discute a historicidade das práticas transgressoras de Luz Del Fuego (ao mesmo tempo pessoa e personagem) a partir de distintas narrativas produzidas sobre ela e por ela. Aborda os significados do gesto de desnudarse $e$ indaga os limites do reconhecimento de Luz como uma feminista... Por último, analisa a experiência radical que marcou sua luta pela liberdade do corpo e do prazer como um modo de subjetivação rebelde, que dinamizou tecnologias anticoloniais de gênero nos trópicos.
\end{abstract}

Palavras-chave: Cinema, Feminismo, Rebeldia, Luz Del Fuego, Vedetes.

\footnotetext{
* Recebido em 22 de janeiro de 2020, aceito em 19 de fevereiro de 2020. Uma primeira versão deste artigo foi apresentada no Fazendo Gênero 11 (2017) e na SOCINE (2017). Agradeço aos participantes pelas considerações e questões que ajudaram a dar ao texto sua forma final. Agradeço às leituras atentas e generosas de Gilberto Sobrinho, Jacy Seixas e dos/das pareceristas anônimos/as.

** Pesquisadora do Núcleo de Estudos de Gênero Pagu, Professora dos programas de Multimeios/ Instituto de Artes e do Doutorado em Ciências Sociais, ambos da Universidade Estadual de Campinas, Campinas, SP, Brasil. kbessaboa@gmail.com / https://orcid.org/0000-0002-5867-5372 
Luz(es) Del Fuego: Feminism and Rebellion

\begin{abstract}
The article presents a reading of the film Luz Del Fuego (1982), by David Neves, taking a critical feminist approach, which links historical and film analysis. It discusses the historicity of Luz Del Fuego's transgressive practices (both person and character) from distinct points of view produced about her and by her own book. The article addresses the meanings of the gesture of stripping and asks the limits of the recognition of Luz as a feminist. Finally, it analyzes the radical experience that marked her struggle for freedom of the body and pleasure as a mode of rebellious subjectivation, which dynamized anti-colonial gender technologies in the tropics.
\end{abstract}

Keywords: Feminism, Luz Del Fuego, Film Analysis, Rebellion. 


\section{Abertura}

Na peça em que trabalho, há uma cena em que eu venho dançando luxuosamente até a plataforma, que fica rente à primeira fileira das poltronas. E vejo, espantada, como as mulheres me olham, de uma maneira que nem eu mesma sei como classificar. Parece que me querem comer com seus olhos em fogo! (Luz Del Fuego/1950)

Luz Del Fuego (1982) ${ }^{1}$, de David Neves, é uma cinebiografia da artista e escritora Dora Vivacqua/Luz del Fuego (1917-1967), que ficou conhecida por se apresentar nos palcos protagonizando peças do teatro de revista, seminua e enrolada em uma cobra jiboia gigante. A primeira vez que vi o filme, por volta de 1985, não conhecia absolutamente nada sobre a trajetória de Luz. Naquele momento, percebi o quanto as imagens de nudez mexiam com várias camadas históricas do nosso imaginário brasileiro sobre a feminilidade, marcado por uma herança colonial, que além de erotizar os corpos femininos, na maioria dos casos de modo sexista, reitera o vínculo entre feminilidade, sedução e pecado.

\footnotetext{
${ }^{1}$ Nome artístico da dançarina e atriz, que segundo consta em sua biografia, foi retirado de um batom argentino que fazia sucesso na época. De acordo com o Jornal O Globo, em matéria de 2017: "Ao ser a primeira atriz no país a aparecer nua em um palco, foi presa e teve que pagar multa na delegacia pelo ato. Ao longo de sua vida foi autuada por causar congestionamentos de carros e expulsa do Theatro Municipal num baile de carnaval após se fantasiar de Noivinha Pistoleira e dar tiros de revólver no teto do teatro. Já com mais de 40 anos era uma obstinada defensora do nudismo. Luz Del Fuego arrendou da Marinha uma ilha na ainda paradisíaca Baía de Guanabara. Viveu numa casa de palha, uma oca, erguida por ela e amigos, e construiu aos poucos duas casas" [http://acervo.oglobo.globo.com/em-destaque/luz-del-fuego-dancarina-atriz-quepioneira-do-nudismo-na-america-latina-20904612\#ixzz4r1cnO4Ko].
} 


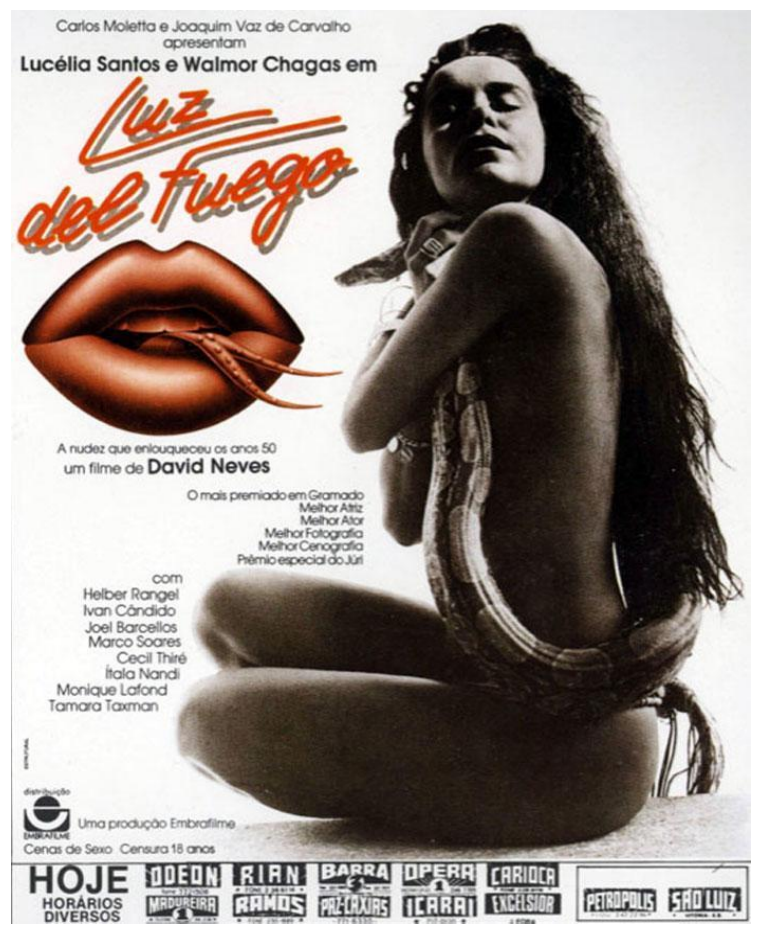

Figura 1: Material de Divulgação do Filme Luz Del Fuego (Neves, 1982) - Embrafilme.

No decorrer da narrativa, ao colocar a personagem Luz no limiar entre razão e loucura, o enredo torna explícito o contraste entre a "modernização do Rio de Janeiro" e o desejo da dançarina de despojar-se através do gesto de retirar as vestes e, junto às mesmas, as máscaras sociais conservadoras que persistiram na cultura urbana. Aliado a este despojamento está em primeiro plano sua ligação com o prazer de viver sem submissão à moral cristã ou às convenções da conjugalidade moderna, embebida do amor romântico que, segundo Luz, coroava de hipocrisia a relação direta entre casamento e procriação. 
Fica claro no filme (e aos poucos em outros documentos fora da tela) que para Luz, a modernidade era justamente o ato de se livrar das convenções do matrimônio monogâmico, abrindo espaço para outros arranjos afetivo-sexuais. $\mathrm{O}$ filme não mostra em detalhes as várias lutas travadas pela protagonista contra os limites sociais impostos a uma mulher considerada independente no momento histórico vivido por Luz. No entanto, evidencia o suficiente para mostrar como a personagem fora enredada $e$, algumas vezes, aprisionada, como consequencia de sua rebeldia, o que a colocava em um estado permanente de vulnerabilidade. Assim, o enredo expõe, ainda que precária e estereotipadamente, as múltiplas formas de violência que culminaram em sua trágica morte.

Antes de adentrar na análise propriamente filmica, gostaria de refletir sobre as possíveis razões que levaram à produção desta biografia ficcional de Luz del Fuego, em um momento (1982), no qual nos aproximávamos de um desfecho de quase duas décadas de suspensão violenta dos direitos democráticos no país. Apesar de na época de sua morte (1967) terem atribuído o crime a dois pescadores, há uma série de perguntas mal respondidas que aguçam nossa imaginação, em especial, por ser um dos anos mais brutais da vigência do regime militar e por Luz, de acordo com o enredo do filme, mas não só ${ }^{2}$, ser uma pessoa não grata pelo regime.

Agnaldo Silva e Joaquim Vaz de Carvalho (1982:50) terminaram o prefácio do livro/roteiro do filme Luz del Fuego com a seguinte reflexão:

(...) neste final de século, já é possível dizer (como nós fazemos desde aquela época), sem causar espanto, que a última leva de prisioneiros políticos a ser anistiada é a dos que foram acusados dos chamados "crimes de costumes"; uma categoria na qual Dora Vivacqua, Luz del Fuego, essa

\footnotetext{
${ }^{2}$ Para escrever este artigo consultei várias edições do jornal Diário de Notícias, Correio da Manhã, O Globo, A Tribuna e Última Hora, disponíveis online pela Biblioteca Nacional.
} 
mulher de muita raça e extrema coragem, se enquadrou, de modo perfeitamente lúcido e consciente, a vida inteira. Círculo, ilha, prisão: é dessa maneira que vale a pena lembrá-la - como uma guerrilheira contra a moral e os bons costumes. (...) Assim, deixamos bem claro como a queremos lembrada: como uma das figuras mais representativas de sua época; como uma mulher digna do maior respeito.

Embora os intentos dos roteiristas estejam claramente enunciados no livro, adianto que o filme é omisso em nos revelar a guerrilheira na luta contra o moralismo. Ao produzir uma personagem marcada por um forte tom de excentricidade $e$ histeria, o enredo mais reitera os julgamentos que a debilitaram ao longo de sua vida do que reforçam as camadas subjetivas $e$ políticas de sua delirante (e talvez por isso mesmo tão potente) revolta (aparentemente) moral. O contexto de produção do Luz del Fuego filme esteve marcado por um forte legado de um cinema brasileiro de cunho erótico e machista, que tinha no sexo $e$ na nudez seu grande apelo de sucesso de bilheteria.

O filme de David Neves figura em $125^{\circ}$ lugar em uma lista de 513 filmes brasileiros produzidos entre 1970 e 2018 que tiveram mais de 500.000 espectadores. Em 1982, apenas 12 filmes nacionais tiveram público similar, sendo o de Neves o primeiro da lista, com 1.751.930 espectadores. Esse relativo sucesso com uma cinebiografia de uma mulher avant la lettre, havia sido realizado antes por Carlos Diegues, com o seu famoso Xica da Silva (1976), com surpreendentes 3.183.582 milhões de espectadores para assistirem a vida, narrada de forma não menos excêntrica $e$ estigmatizada, de uma ex-escrava da corte portuguesa, que havia vivido maritalmente com um riquíssimo contratador de diamantes. $\mathrm{O}$ que liga a Xica de Diegues à Luz de Neves é o modo como representam a relação entre rebeldia e sexualidade, hipererotizando as cenas de nudez de ambas as personagens, ao ponto de criar um vazio iconográfico entre o corpo nu e a liberdade e ousadia que tal nudez poderia/deveria representar $e$ enunciar. Em outras palavras, estetizam de um modo que 
despolitiza, porque torna caricatura e espetáculo o encontro entre rebeldia e liberação sexual.

A maioria das cinebiografias brasileiras, produzidas até os anos 2000, de mulheres rebeldes foram feitas por homens ${ }^{3}$ (roteiristas e/ou diretores), com a exceção do Eternamente Pagu de Norma Bengell, ainda nos anos 80, Carmen Miranda: Banana is my Business (1995), de Helena Solberg, e do filme de Carla Camurati, Carlota Joaquina, Princesa do Brasil ("princesa rebelde"), também nos anos 90. Em contraste, nenhum destes últimos filmes apelou à exploração do corpo nu e do sexo como recurso dramático. Como resultado, apenas o de Camurati figura na lista da Ancine com mais de um milhão de espectadores. Seria apenas uma questão de bilheteria? A literatura feminista de análise filmica, desde a década de 70, nos ensina que não (Thornham, 1999). A erotização objetificadora do corpo feminino antecede o próprio cinema e o mesmo nasce reatualizando este imaginário, até mesmo quando intenciona desconstruí-lo.

A aliança entre erotismo e rebeldia não é um problema em si, muito menos corpos nus, pelo contrário, expõem a corporalidade e sua gestualidade em sua forma de linguagem política plena. A interpelação que uma longa tradição feminista faz é questionar os motivos pelos quais os usos do erotismo quase sempre ocorrem no interior de uma estética que subjuga as liberdades femininas e a própria feminilidade, enquadrando-as de modo explícito numa relação subalterna para com a masculinidade hegemônica viril e dominadora. Parte desta estratégia de construção do olhar de um espectador desejante se dá em função do voyeurismo masculino ${ }^{4} e$ dos processos de

\footnotetext{
${ }^{3}$ Recentemente, a regra parece prevalecer-Elizabeth Bishop-Flores Raras (2011) direção de Bruno Barreto, Elis (2016), direção de Hugo Prata; Nise: o coração da loucura (2015), direção de Roberto Berliner. Nos documentários, a presença feminina na direção muda um pouco o cenário: Clementina (2018), direção de Ana Rieper e My name is now- Elza Soares (2018), de Elizabeth Campos.

${ }^{4}$ Alguns textos clássicos dos estudos fílmicos feministas abordam a questão do prazer do olhar de um espectador imaginado como masculino, atualizando um debate entre psicanálise e cinema a fim de questionar o inconsciente patriarcal que permeia o cinema em sua estética e conteúdo. Dentre eles cabe mencionar:
} 
mimetização e de produção de estranhamento de feminilidades rebeldes. A produção do exotismo rebelde é um dispositivo colonialista poderoso e ativo no campo das produções visuais desde o início da modernidade, reatualizado no estrondoso modo de produção do star system. Nesse jogo representativo os espectadores não são neutros, possuem uma história semiótica $e$ social, não apenas percebem as imagens, mas participam do processo de significação das mesmas (Lauretis, 1981). Luz del Fuego não desestabiliza essa estrutura desigual do jogo sujeito/objeto do olhar $e$ das desigualdades de gênero subentendidas ali. No entanto, é justamente esse intervalo de histórias entre o tempo vivido e o tempo narrado que instiga a fazer do filme um leitmotiv para esta reflexão.

O que me move neste este reencontro com Luz Del Fuego, o filme, é justamente a sua relação entre a facticidade $e^{5}$ a não facticidade (Adorno, 1970). O emaranhamento de camadas de cenografia (o teatro, a ilha, a cidade); a correlação entre corposmemória e corpos-fetiche (Canevacci, 2006). Um diálogo com a história do nu e do sexo no teatro e no cinema (Krzywinska, 2006); das relações entre a economia política das subjetividades $e$ das estéticas postas tanto pelas molduras do filme quanto por seu conteúdo ficcional (Rolnik, 2018). Num plano mais geral de

Laura Mulvey (1974; 1996), Ann Kaplan (1990) que acrescenta à perspectiva de Mulvey uma importante crítica ao caráter ambíguo da psicanálise como instrumento de análise feminista, na medida em que reatualiza um discurso opressor que coloca as mulheres em posição submissa. De modo ainda mais crítico, figura o texto de De Lauretis (1987) que indaga o que seria subversivo no cinema de vanguarda $e$ as potências do cinema narrativo na produção/desconstrução das tecnologias de gênero.

${ }^{5}$ Embora eu tenha alguns desacordos com a Teoria Estética, é preciso reconhecer a relevância da crítica de Adorno ao estudo da arte na perspectiva subjetivista em voga na ocasião. A fim de argumentar uma visão materialista histórica da arte, ele sugere olhar para sua produção como emergência, um processo de individuação que é sempre coletivo e social. A relação entre a sua facticidade e a não facticidade (espírito) permite pensar sua autonomia e ao mesmo tempo sua relação intrínseca com o seu tempo/espaço. Foge assim das armadilhas das intencionalidades ou do estudo da recepção (efeitos) como instância valorativa da obra artística. 
pesquisa, tenho interesse em explorar as variações, as intertextualidades, as muitas referencialidades de figuras singulares como Luz del Fuego e todo um universo de fantasias que ainda desperta. Como esse pensar é amplo e não cabe num único artigo, a reflexão proposta aqui circunscreve-se à, historicidade de diferentes narrativas sobre Luz Del Fuego e o que essas muitas histórias nos dizem do feminismo, da rebeldia e da solidão dos que enfrentam na carne o contrafluxo do modo de vida não ordinário.

\section{Cenários e Fantasias}

Uma vedete e suas cobras, nos palcos, nos salões dos carnavais, tomam conta do imaginário libidinal de um país, sai nos jornais da época, nas revistas, desperta curiosidades mórbidas, desejos de poderosos, alimenta discórdia de mulheres engajadas na defesa puritana do lar e da maternidade. Um pouco disso tudo alimenta, cena após cena, a caracterização de uma vida que não se contém nos limites que lhe querem impor. No seu conjunto, o filme destila todo um repertório de imagens-padrão de corpo desejável e mulher de "gênio forte", o corpo-fetiche. Luz, é apresentada como uma mulher consciente de suas capacidades de mobilizar as libidos alheias para satisfação de seus próprios caprichos e desejos. Afinal, uma verdadeira sedutora é ao mesmo tempo aquela que ganha o afeto de seus admiradores e os manipula ao seu bel prazer. Importante notar o quão potente é este domínio, tanto para a sobrevivência de Luz no âmbito material (trocas, favores), quanto para abertura de linhas de fuga de uma subjetividade rebelde que não se conforma ao destino que lhe estava reservado, no âmbito de uma família falocêntrica, heterormativa e monogâmica; tripé este que cria a expectativa de que, enquanto filha de uma família abastada venha cumprir o ideal da mulher-mãe, figura essa que assombra a personagem, como um corpo-memória que ela rejeita.

No seminal livro de Bernardet, escrito em 1967, o autor destaca a existência de um cinema nacional devoto do triângulo 
sexo, abjeção e anarquia, seja por motivos comerciais, sensacionalistas, seja por motivos sociológicos. Não por coincidência, várias peças teatrais de Nelson Rodrigues foram adaptadas para filmes ${ }^{6}$, trazendo temas como: virgindade, estupro, ninfomania, pederastia, lesbianismo (sic), prostituição, incesto $e$ políticos hipócritas. Nas palavras de Bernardet: "burgueses enriquecidos comportam-se como imperadores romanos aos quais o dinheiro dá todo poder sobre os outros". Desse modo, aproximadamente uma década depois da escrita de Bernardet, no redespertar da democracia brasileira, o filme Luz Del Fuego (1982) já não abalou ao desfilar incansáveis planos de nudez de sua atriz (Lucélia Santos) interpretando a vedete naturista Luz Del Fuego. Julgo que tal fato se deve, ao menos em parte, há uma década ou mais de exposição visual às pornochanchadas, além das muitas reiterações do corpo feminino erotizado nos diversos espaços culturais e de entretenimento, por exemplo, o amplo sucesso das mulatas do Sargentelli, que apareceram também na pornochanchada de 1977, As Granfinas e Camelô (Ismar Porto).

Além de não chocar, tampouco despertou solidariedade ou simpatia por sua causa libertária, como se pretendia. As vedetes dos anos 1920 a 1950, que escandalizavam com suas duas peças em palco, soavam distantes e démodé para uma geração mais próxima do imaginário hippie e americanizado das noções de liberdade e corporalidade. Se não fora pelo escândalo, ao menos certa curiosidade histórica pelo universo das vedetes, do teatro de revista e a nudez no palco parece ter mobilizados espectadores. Afinal, o filme foi um sucesso, tanto quanto o fora antes o próprio teatro de revista e suas famosas vedetes.

\footnotetext{
${ }^{6}$ Embora as referências de Bernardet fossem apenas das adaptações ocorridas até 1967, apresento aqui uma lista maior dos filmes baseados nas peças de Rodrigues: Bonitinha, mas ordinária (1963 e 1981, com Lucélia Santos); Vestido de Noiva (2006); Traição (1998); Boca de Ouro (1963); Perdoa-me por me traíres (1980); Engraçadinha (1981); Álbum de Família (1981); O beijo no asfalto (1981); Os sete Gatinhos (1980); A dama do Lotação (1978); O casamento (1974); Toda Nudez será Castigada (1973); Engraçadinha depois dos 30 (Asfalto Selvagem) 1966; O Beijo (1965).
} 
O Teatro de Revista colocava fatos da atualidade nos palcos, misturando música e dança, "através do uso da paródia, da zombaria, do burlesco, do sensual e do sexual não explicitado, mas insinuado através de duplo sentido, do jogo, da teatralidade" (Antunes, 2002). O estudo de Delson Antunes sobre os inícios do teatro de revista salienta que a chegada da companhia francesa Ba-Ta-Clan entre 1922 e 1923 trouxe pela primeira vez a valorização da participação feminina, pois as atrizes foram incluídas nas chamadas publicitárias das peças teatrais. Dentre as novidades, há um apelo erótico com o nu artístico, expondo a nudez de seios, braços e pernas sem as grossas meias, típicas dos espetáculos da época. A essa exposição dos corpos franceses agrega-se à cena um novo padrão estético-corporal: magras $e$ esguias, com corpos torneados por coreografias bem estudadas $e$ com grande domínio técnico (Antunes, 2002).

Figura 2: Luz del Fuego- Fonte: Verdade Nua, 1950

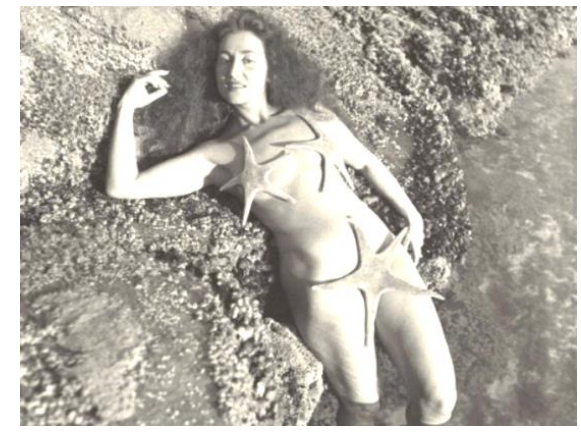

Figura 3: Lucélia Santos (Luz del Fuego)- Fonte: Fotograma do Filme

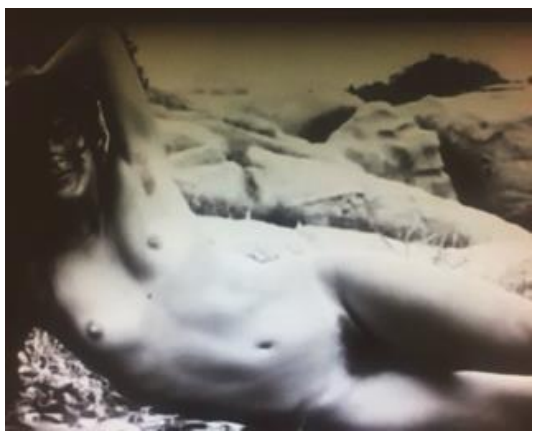


Se nos anos 1940 Luz não tem este perfil (Figura 2), nos anos 1982 a atriz Lucélia Santos (Figura 3), com apenas 24 anos na ocasião de filmagem, é a descrição perfeita do novo padrão, já não tão novo. $\mathrm{O}$ corpo da atriz, apesar de mignon, na estatura $e$ no volume dos seios e na discrição dos músculos torneados, deuse a ver no filme em ângulos de volúpia capazes de capturar o prazer voyeurístico dos espectadores e suas fantasias de consumo erótico, afinal, a nudez da personagem se estende para além das cenas de palco.

O filme narra os primeiros encontros de Luz Del Fuego com o palco e logo atrela seu sucesso ao suporte artístico e existencial promovido pelo seu coronel ou como insinua logo na abertura, o sugar daddy senador João Gaspar.

O Senador João Gaspar (Walmor Chagas $^{7}$ ), narrador do filme, nos dizeres do roteirista Carvalho é um personagem simbólico, pois a partir dele se percebe um conjunto de relações que Fuego mantinha com os seus vários amantes (políticos, militares, policiais). Frágeis e feridos em suas honras (e finanças), o arquétipo de uma masculinidade bélica será o pivô ficcional que interrompe violentamente a vida de Luz personagem.

A estreita conexão entre vedete, dançarina de teatro de revista $e$ amante de poderosos ${ }^{8}$ não era prerrogativa única de Fuego, como muitas biografias de vedetes brasileiras no permitem aferir. A diferença incômoda de Fuego é que ela deixava explícita sua independência sexual $e$ suas posições políticas, que envolviam a defesa de uma alimentação vegetariana e do nudismo, à liberdade de manter relações sexuais e amorosas com quem

\footnotetext{
${ }^{7}$ Walmor Chagas também atua em Xica da Silva como o Senhor rico que se enamora de Xica e lhe faz todas as vontades. O ator incorporava características marcantes de uma masculinidade rica, branca, heterossexual e liberal, com uma dose fina de ironia, de quem usufrui das estruturas que produzem as desigualdades, ao mesmo tempo as desafiando.

${ }^{8}$ Aos textos acadêmicos sobre o assunto se soma o documentário As Vedetes do Brasil (Dimas Oliveira Junior e Felipe Harazim-2003), realizado para a Rede stv sesc senac de televisão. O documentário apresenta uma visão panorâmica das atrizes do teatro de revista, com entrevistas e imagens de arquivo.
} 
quisesse, sem se limitar aos ditos de instituições, cujas referências eram o casamento ou a monogamia. Essa visão libertária, sem vínculo direto com filosofias anarquistas ou marxistas ${ }^{9} e$ anterior à expressiva luta feminista da chamada segunda onda, foi traduzida no filme na ótica do espetáculo, da indiscrição, do exibicionismo, justamente porque perdeu essa dimensão social mais ampla. Torná-la singular é uma estratégica retórica comum no expediente de criação do "herói", no caso, da "heroína", ou seja, transporta seus feitos para ordem do extraordinário, do pitoresco, do exótico e do incomum. ${ }^{10}$

Sua irreverência se faz notar na tela tanto na liberdade de expor o corpo (nudez frontal, proibida pela censura até pouco tempo antes do lançamento do filme), quanto no modo como se defende de uma bárbara cena de estupro em uma de suas prisões, quando divide cela com vários homens. Um deles, Agildo (Marco Soares), acompanha a personagem de Luz por todo o restante da narrativa, sendo um amigo constante e fiel. A parceria Luz/Agildo funciona como uma aliança entre os diferentes tipos de corpos/vidas marginalizados, de um lado, uma vedete dos palcos e da vida, ateia, assumindo suas escolhas amorosas e sexuais e, de outro, um gay efeminado, negro, envolvido com a polícia de costumes. Ambos expostos à fúria e ambiguidade (misto de desejo e rejeição) com a qual a moral hegemônica lida com as sexualidades e modos de vida dissidentes. Ambos unidos pelas margens produzidas no jogo desigual das alteridades.

Apesar de lidar com um tema histórico e tabu, ou seja, a primeira naturista/nudista brasileira que tentou politizar a nudez do corpo para além de sua espetacularização, e de seu diretor ser um dos nomes que passaram a figurar como integrante do cinema novo brasileiro, a proposta estética do filme pouco difere de uma

\footnotetext{
${ }^{9}$ Por exemplo, o romance de Patrícia Galvão, Parque Industrial (1933), que expressa ideias libertárias numa perspectiva marxista, com ênfase em mulheres proletárias e incluindo o debate racial.

${ }^{10}$ Lauretis nos chama a atenção para a ambiguidade desta estratégia retórica $e$ aponta os limites de sua eficácia, em seu texto "The Rethoric of Violence" (198384).
} 
estrutura clássica, com clichês de esquetes cômicos salpicados ao longo da narrativa $e$ construção de personagens gestual $e$ cenograficamente caricatos e estereotipados. Ao investir no mito $e$ não na mulher Luz Del Fuego abriu algumas liberdades criativas, porém frustrou em desvelar o que o mito produz em termos de compreensão das instituições sociais $e$ das relações homens/mulheres.

Um exemplo do caráter estéreo da mitificação da personagem é o modo como a passagem do tempo se faz notar nos usos do corpo da atriz para a personagem. Embora no roteiro fique claro que o encontro entre o Senador e Luz tenha sido no início de sua carreira como vedete no Rio de Janeiro, portanto, na década de 1940 e terminado em um presente, no qual o Senador relembra a morte de Luz, na década de 1960, quando esta teria por volta de cinquenta anos, o corpo que lhe assombra a memória é de uma Luz jovem, que não sofreu as marcas do tempo. Um mito ${ }^{11}$ produzido no imaginário cinemático não tem

\footnotetext{
${ }^{11}$ Mito não no sentido de Mircea Eliade (1994), que fornece os modelos para a conduta humana, conferindo, por isso mesmo, significação e valor à existência. Mito e mitificação no sentido que lhe atribuiu a obra pioneira de Edgard Morin (1957), ao analisar a constituição do star system na relação projeçãoidentificação. Morin chama atenção para o dispositivo da "boa-garota-má" cujo sex appeal brinca com o imaginário da vamp (impura, assertiva, provocativa, amizades suspeitas), mas no final revela-se pura, generosa. $\mathrm{O}$ autor chama atenção também para a diferença de gênero na produção da star, visto que para ele as mulheres são mais idealizadas, mais fabricadas e adoradas, por isso mesmo menos reais. A década de 1970 e 1980 trouxe importantes debates feministas para os estudos filmicos a fim de problematizar o stardom, analisam as performances/vidas de atrizes imortalizadas pelo cinema hollywoodiano apontando o alinhamento do aparato cinemático ao mecanismo psíquico masculino. Mollie Haskell, Laura Mulvey, Gaylyn Studlar, Jackie Stacey, Andrea Weiss e bell hooks são autoras fundamentais na construção de uma interlocução entre o star-system e os estudos sobre espectadores, ampliando a polêmica para além do olhar masculino, do lésbico e da mulher negra. Um conciso balanço crítico de toda esta produção pode ser encontrado Desjardins (2018). Embora não seja central, vale registrar o uso que David Neves faz de códigos do star system para narrar a vida de Luz Del Fuego, por isso seu investimento na lógica da mitificação.
} 
temporalidade, nunca perde o frescor, embora dependa da memória para sobreviver.

\section{O senador-narrador: jogo de perspectivas}

João Gaspar é uma personagem-tipo na construção de visibilidades para os trânsitos marcadamente hipócritas das relações entre a figura masculina pública e a privada, ou melhor, nos faz indagar quantas masculinidades o habitam?

Figura 4: O Marido

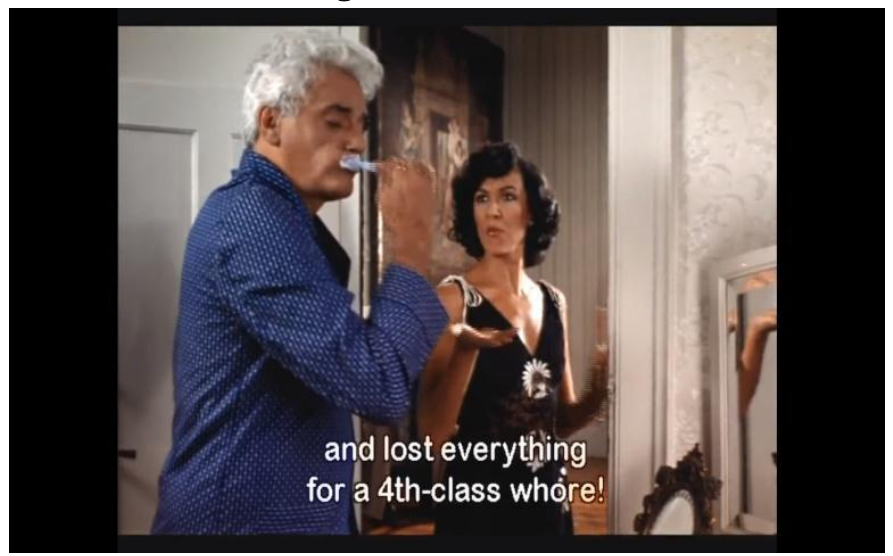

Figura 5: O Amante

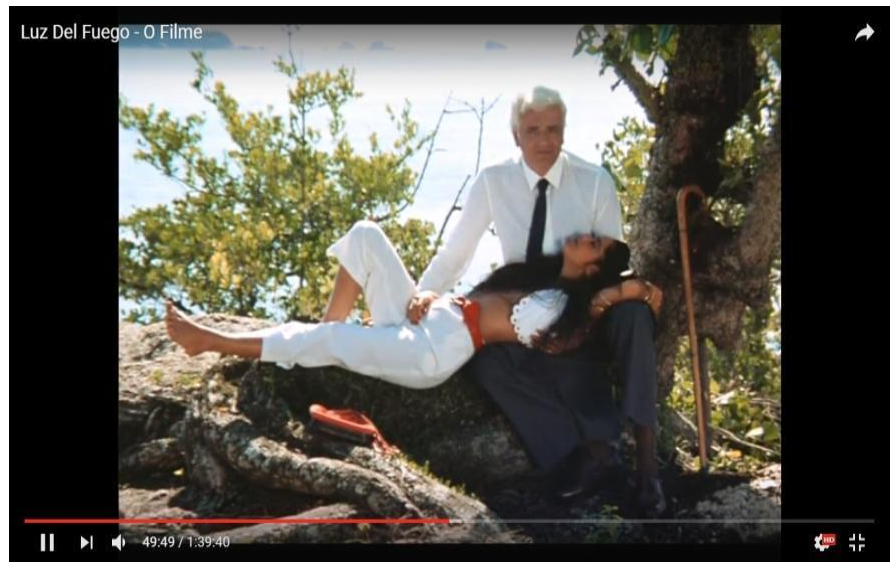


Figura 6: O coronel (o chapéu e o charuto o colocam em posição hierárquica superior, acima da personagem vestida de terno e gravata).

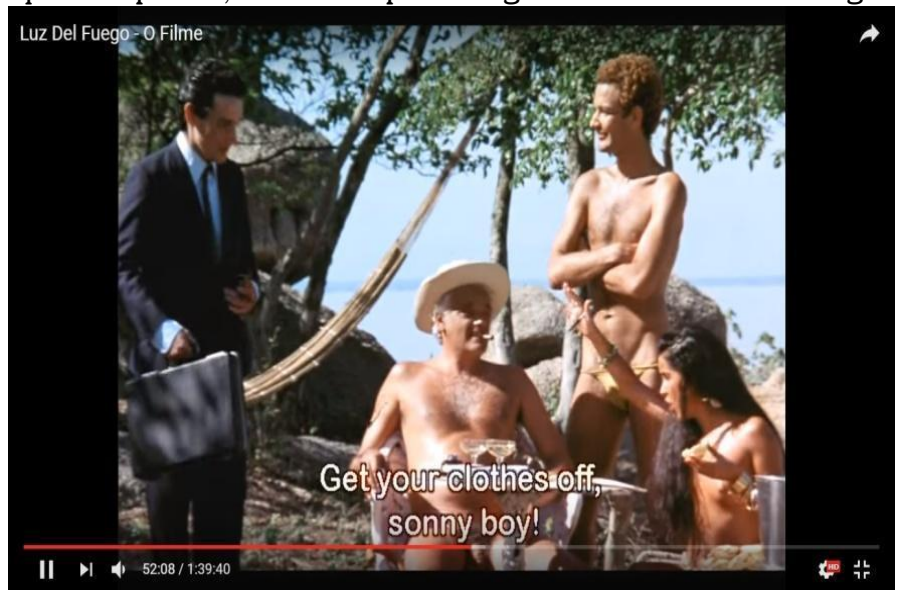

Suas facetas são tão deslizantes entre normas, valores $e$ vivências morais que seu cargo de político ("ele não sabe fazer outra coisa" - sentencia sua preocupada esposa) é o corolário desse jogo de cintura, totalmente coerente com sua performance de homem de poder e ao mesmo tempo o sugar daddy. Ele pode: burlar censuras, retirar protegidas da prisão, controlar a mídia, manipular correligionários do partido, silenciar a filha e a esposa, presentear a vedete com casas milionárias, apoiar e retirar o apoio às produções artísticas que levam modernidade à vida urbana carioca. No entanto, para além de todo este poder esclarecido, Luz Del Fuego é uma personagem que lhe escapa. Ao mesmo tempo, fruto de sua imaginação $e$ invenção e culpabilizada pelo seu (trágico) destino.

Corrupção (troca de favores com recursos públicos, a partir de relações hierárquicas para obter vantagens) é uma das lógicas orientadoras das relações no decorrer do filme. Várias personagens que gravitam em torno da aplicação ou elaboração de leis e normas compõem um arsenal complexo entre delegado, policial, senador e juiz. Um jogo social de subterfúgios, pequenos 
podres poderes e manipulações de toda ordem, com protagonismo (embora não unilateral) masculino é o subtexto do filme. Aliado a isto, as falas/imagens sugerem um significativo crescimento conservador no início dos anos 60, diferente das permissividades veladas vivenciadas entre os 40 e 50. É como se fosse o prenúncio do golpe militar e toda a censura brutal que viria em sua esteira.

\section{Duas-peças e nudismo - onde mora o perigo?}

Deslizante nesta dupla moral está também a caracterização das personagens femininas. As duas peças (biquíni) que caminham dos palcos e vedetes para as areias de Copacabana permanecem sob vigilância atenta da tradicional família brasileira e de suas polícias e patrulhas dos corpos. A trama passa superficialmente pelas sexualidades lésbicas/gays, e a nomenclatura utilizada remonta à violência verbal e física contra homens gays efeminados, como no caso da luta entre Jacaré (um prisioneiro que tenta estuprar Luz) e Agildo (que a defende). Jacaré desafia Agildo xingando-o de "boneca". Ao longo do filme, o significante boneca terá seu sentido reconfigurado para uma figuração de gênero (não mais uma sexualidade dissidente) num musical escrito pelo personagem Indalécio (Helber Rangel), que apresenta, nos intervalos dos shows de Luz Del Fuego, números protagonizados por mulheres travestis. Numa cena menor, Indalécio pergunta para Agildo quem é o menino que estava cantando no palco vestido de mulher e Agildo responde: "A Deise? Menino? Aquilo é moça, das que sentam pra fazer xixi”. O descolamento da inteligibilidade do gênero da relação primária com o corpo para o acento na estilização repetida do gesto é uma instigante percepção de sua performatividade (Butler, 1998), expressa num diálogo informal por uma personagem negra, gay e efeminada uma década antes de sua formulação teórica. No conjunto do filme, essas sutilezas passam despercebidas.

A ilha do sol, lugar da festa bacante dos desnudados, vira, no filme, um delírio exótico promovido por uma mulher 
temperamental. No entanto, também é possível ler a cena pelo seu lado carnavalesco, no sentido bakhtiniano, pois permite deslocar do cotidiano as forças controladoras sobre os corpos e prazeres, liberando o lúdico e afrouxando as regras.

Figura 7: Fotograma de Luz del Fuego (Neves; 1982)

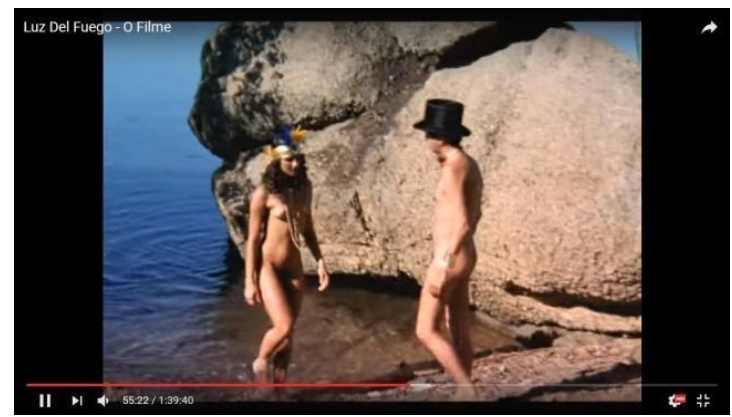

Figura 8: Fotograma de Luz del Fuego (Neves;1982)

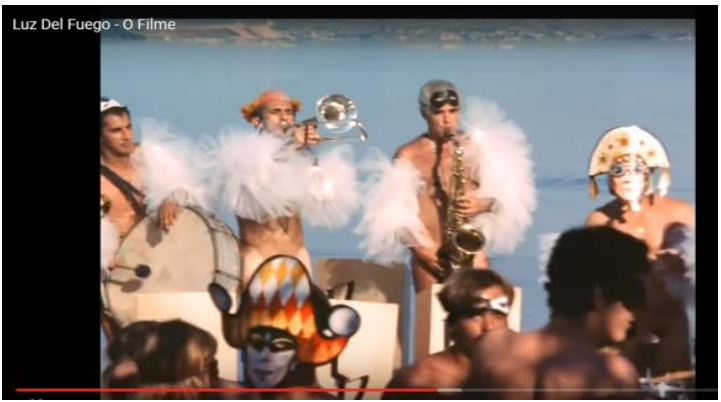

Figura 9: Fotograma de Luz del Fuego (Neves; 1982)

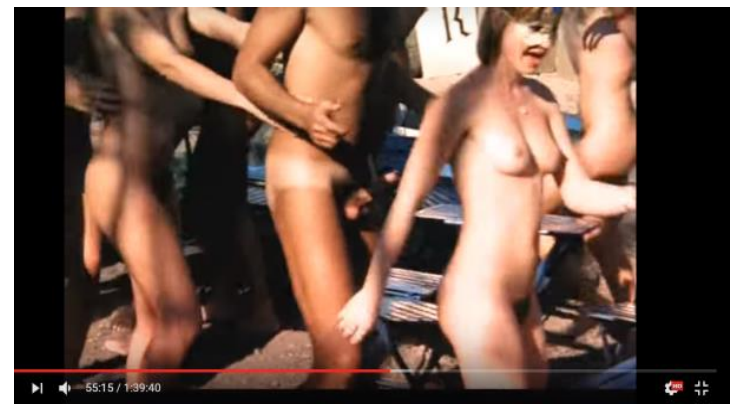


O toque, o riso, o despojamento da dança circular $e$ a velocidade do ritmo de edição criam nessa sequencia uma atmosfera alegre, caótica e anárquica. A festa é uma verdadeira ode à liberdade política da nudez dos corpos pregada por Luz Del Fuego; encenada no registro carnavalesco; o que nos leva à pergunta: como a nudez de Luz é apresentada ao espectador? Diria que há cinco eixos importantes de visualização da nudez de Luz, que aparecerão nos primeiros 15 minutos do filme, repetindo o padrão ao longo do mesmo. 1) relação natureza/nudez: as primeiras imagens que vemos na abertura do filme são de Luz nua confundindo-se com a paisagem curvilínea das pedras ao mar. 2) nudez e perda da inocência: na sequência das cenas anteriores, vemos Luz nos seus 16 anos, ela no camarim de um circo, com um "amante", a sequência termina com um plano no qual escreve com o batom no espelho o seu nome de artista. Um salto no tempo e a vemos de biquíni, seminua no palco cantando que precisa de um coronel. 3) nudez vinculada à sedução/perigo: na delegacia, vemos Luz nua, seduzindo o delegado, brigando com malandros presos e sendo abusada (tentativa de estupro). 4) nudez cotidiana: um pouco à frente na narrativa, está em sua casa, nua com sua cobra. 5) nudez artítica- as várias vezes em que expões-se no palco com suas cobras. O que os diferentes eixos possuem em comum é justamente a configuração narativa da (narcísica?) relação de Luz com a nudez como contraponto e desafio à sociedade protegida pelas máscaras (vestida).

Enquanto vedete, Luz quer as luzes da fotografia e das manchetes dos jornais. A cena em que ela lança o partido Naturista, mantém a atitude espetacular do palco, suas palavrasscript haviam sido ditas pelo Senador em momento lúdico e etílico algumas tomadas antes. O enquadramento do "lançamento" é feito de modo a exacerbar a futilidade inócua de um escândalo que nunca iria dar em nada como se ela não tivesse argumentos para justificar a criação de um partido e não soubesse a importância política desta atitude. O enunciado indica que ela está fazendo tudo para chamar a atenção. Ou seja, a narrativa coloca em segundo plano as lutas da personagem pela emancipação das 
mulheres. O filme não consegue efetivar o valor da personagem porque a desautoriza em momentos cruciais da trama, passando a palavra e o protagonismo para que as outras personagens masculinas falem por ela. Como por exemplo, o próprio senador (quando monta o slogan do partido ou quando expõe a importância do legado de sua trajetória política em comparação com a artística e política de Luz del Fuego; o jornalista Indalécio, o seu amigo e caseiro, Agildo (na ambiguidade que assume, de uma relação extremamente desigual sócio-racialmente e ao mesmo tempo uma das mais afetuosas ao longo da trama), seu amante Canário, ao receber as visitas na ilha e a administrar seu tempo. Tudo isto nos faz pensar na questão da inteligibilidade do corpo $e$ da vida de Luz Del Fuego e nos leva à pergunta sobre quando sua vida deixou de ser viável (Butler, 2018).

Figura 10: O palco- Fotograma do filme Luz del Fuego (Neves; 1982)

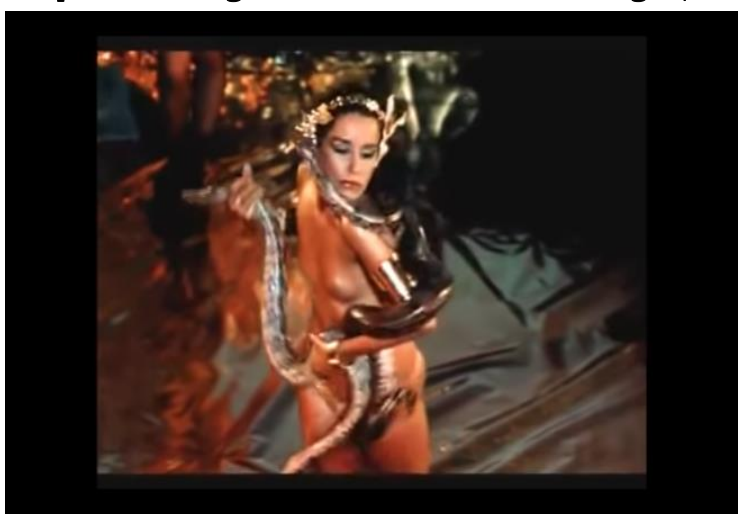


Figura 11: Palco II- Fotograma de Luz del Fuego (Neves; 1982)

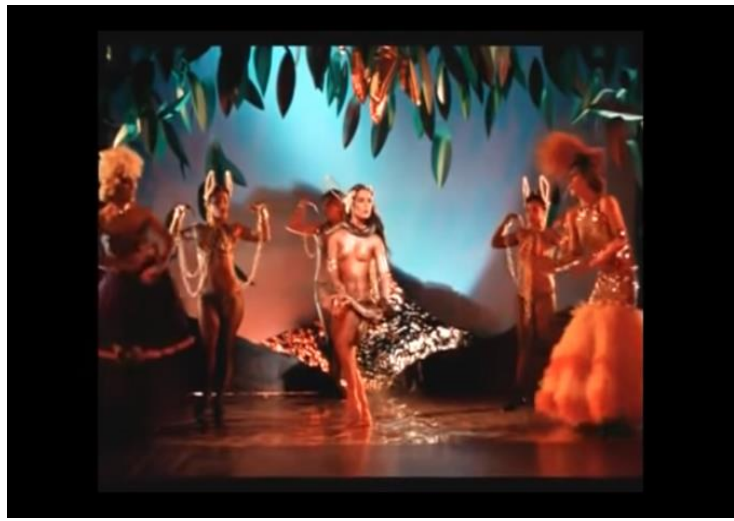

A irreverência de Luz foi aplaudida enquanto esteve circunscrita ao palco, ou seja, ao domar a cobra - signo fálico por excelência - Luz excita uma plateia atônita e curiosa. O tom dourado da pele das bailarinas fez desta cena uma das mais memoráveis do filme. Em contraste, o tom azul das últimas aparições de luz e sua cobra, apesar de claras e cheias de brilhos, realça um tipo de luz fria, emoldurando sua solidão. Domar o falo na vida não é o mesmo que no palco. Nem mesmo o rude pescador/barqueiro, bígamo (no linguajar ciumento de Agildo) encarou sem melindres a força ativa e luminosa de Fuego. Sua radical confrontação das hipocrisias morais para além do palco a tornou alvo de violências explícitas e veladas, algo que se percebe nas entre-imagens do filme.

A força erótica do encontro carnal entre ambos tornou-se visual, sem economia de tempo em planos cheios de ternura $e$ ardor. 
Figura 12: Ritual- Fotograma de Luz del Fuego (Neves; 1982)

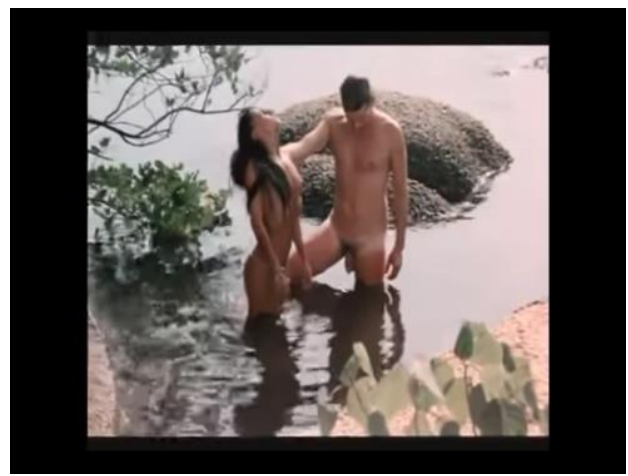

Figura 13: Erotismo- Fotograma de Luz del Fuego (Neves; 1982)

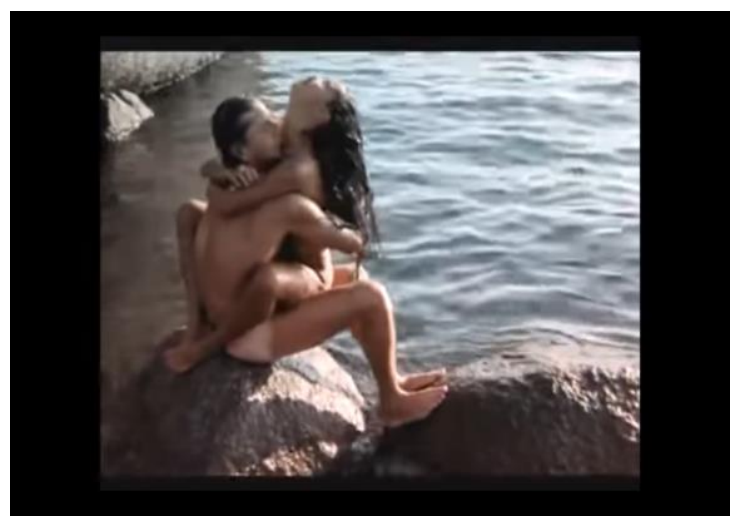


Figura 14: Prazer- Fotograma de Luz del Fuego (Neves; 1982)

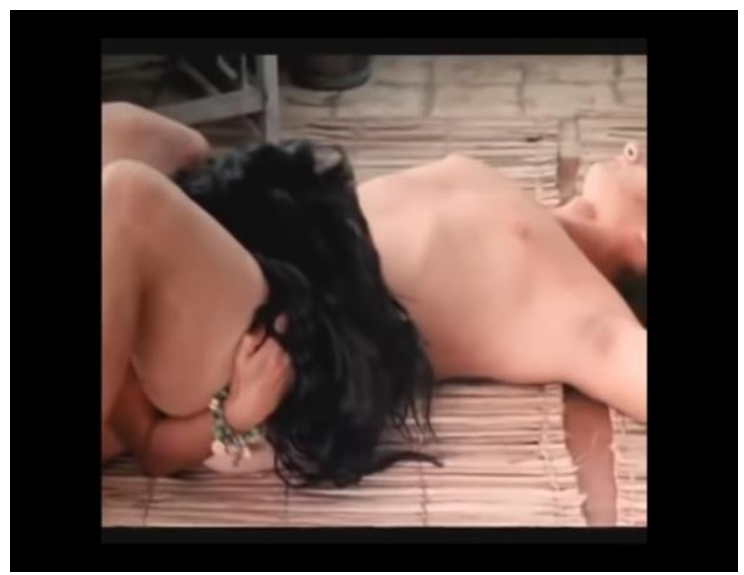

Figura 15: Entrega- Fotograma de Luz del Fuego (Neves; 1982)

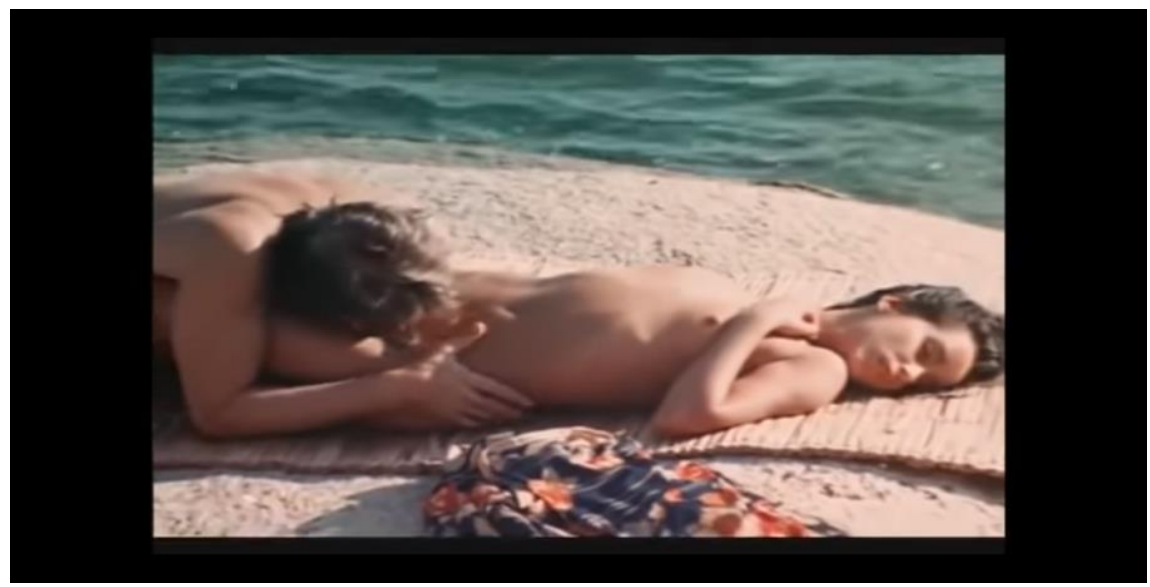

Em contraste à performance utilitária da relação entre Luz e João Gaspar, o casal Luz e Canário foi tratado à partir de uma mise-en-scène que aproximou a película da estética da boca do lixo e, na mesma medida, preencheu a tela de afetos carnais, ressignificando o prazer para além das conjugalidades 
convencionais. O desejo e o ato sexual ali exibido é heterossexual sem ser heteronormativo, não se centra na penetração em si e muito menos no orgasmo masculino (Williams, 2008). O prazer desfrutado no encontro é mútuo. Em outras palavras, sua encenação o aproxima mais da contravenção do que das convenções. Uma das poucas ousadias visuais da trama.

$\mathrm{O}$ adeus da personagem, nativa solitária, fica nos intervalos da narrativa. O gesto aos passantes navegadores da Baía de Guanabara, retoma imagem já disseminada de Luz del Fuego em seu livro e replicada em jornais de sua época.

Figura 16: O adeus- Fotograma de Luz del Fuego (Neves, 1982)

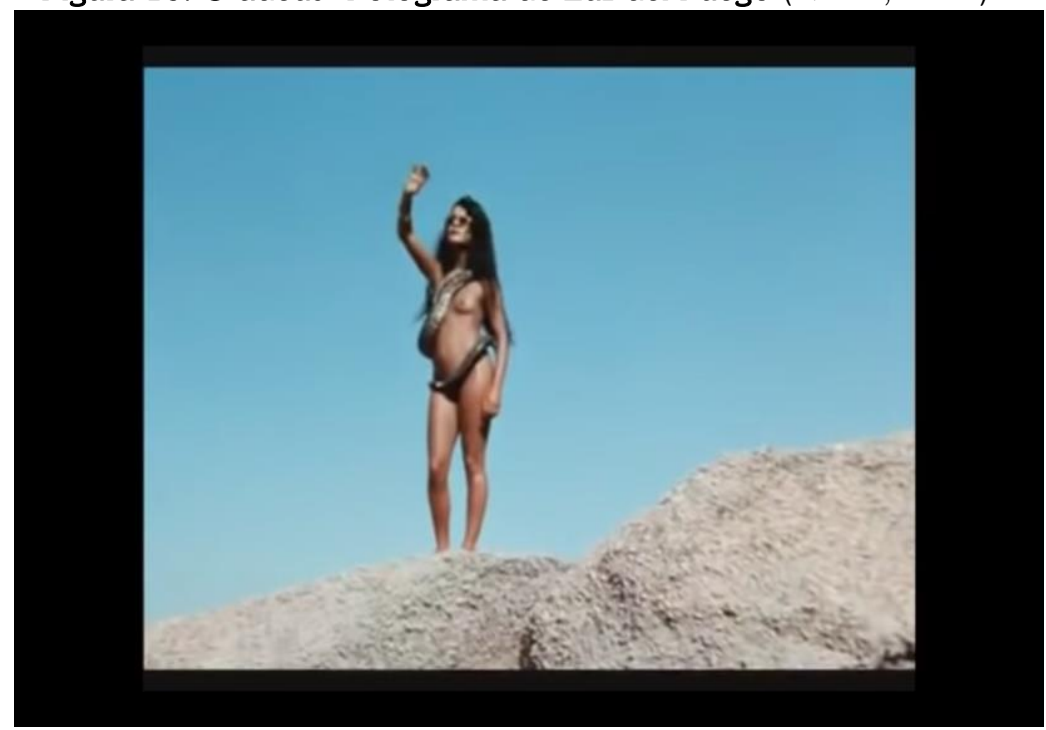


Figura 17: Luz Del Fuego na Ilha do Sol

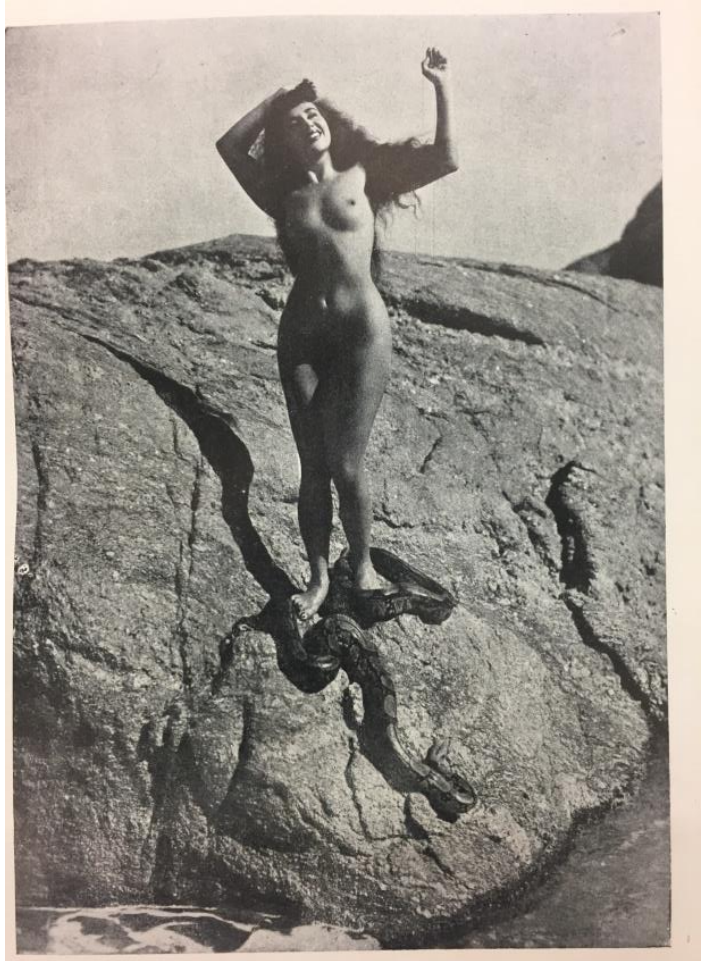

Fonte: Verdade Nua (Fuego, 1949)

De certo modo sim, mas no afã de fazer jus à memória de Luz del Fuego, o final do filme simplesmente é uma grande decepção. Na sequência de sua desaparição imagética da narrativa, a personagem mergulha no mar. Ali, quem não sabe do enredo fica na dúvida se foi um suicídio ou uma entrega. O corte abrupto para a residência do Delegado e as cenas seguintes de perseguição ao assassino, convenientemente atribuído ao amante Canário, forjam uma linha imaginária de vários homens envolvidos em sua morte, ao mesmo tempo em que um dos amigos, Indalécio, faz a denúncia que todos eles são culpados.

Sim, simbolicamente, Luz foi morta não só na representação fílmica, mas no âmbito maior das lutas culturais, por uma 
sociedade conservadora e heteropatriarcal. Ainda assim, o final apoteótico caiu numa armadilha muito comum: deixar a última palavra/imagem àquele que fala por ela. Canário canta: "A Luz há de brilhar mais uma vez". A imagem de Luz que ficou foi dela afundando solitária no mar.

Figura 18: Mergulho- Fotograma de Luz del Fuego (Neves, 1982)

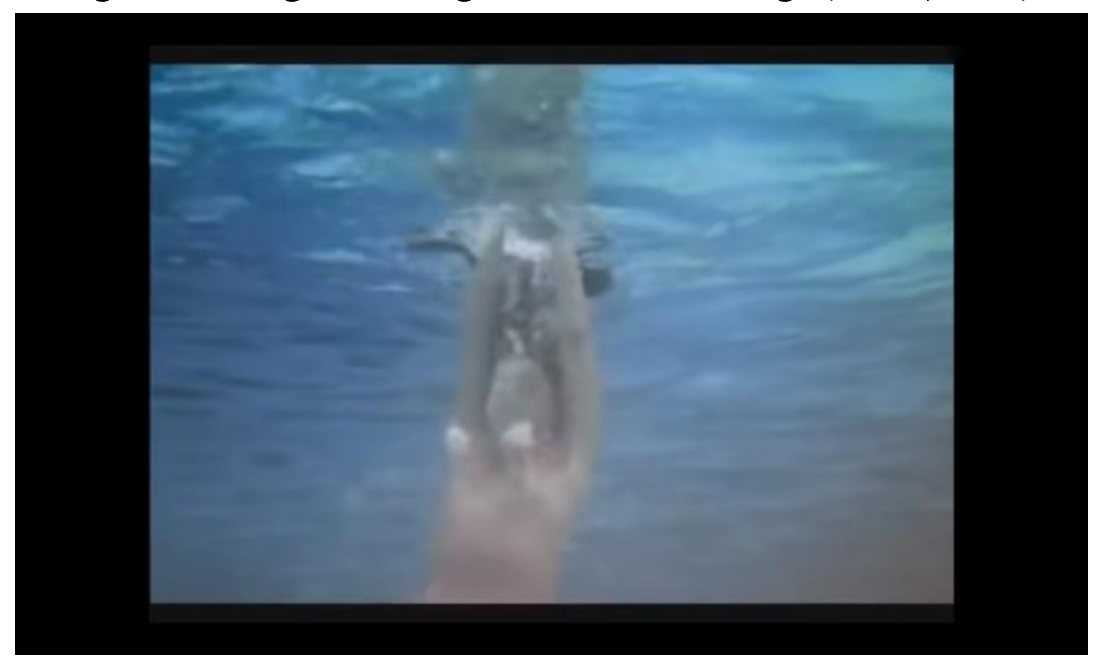

Despatriarcalizar a representação filmica (ficcional ou documental) da história-memória de Luz del Fuego é um trabalho ainda por ser feito; infelizmente a ficção de Neves (1982), neste quesito, foi um desacerto...

Fora de campo: o feminismo de Luz Del Fuego entre ícone, símbolo $e$ vida insubordinada

Eu hoje represento a loucura

Mais o que você quiser

Tudo que você vê sair da boca

De uma grande mulher

Porém louca!

Eu hoje represento o segredo

Enrolado no papel 


\author{
Como Luz del Fuego \\ Não tinha medo \\ Ela também foi pro céu, cedo! \\ (Rita Lee, 1975)
}

$\mathrm{Na}$ apresentação do roteiro do filme (Silva,1982) lê-se uma frase desafiadora: "se algum dia elas (feministas) precisarem de uma protagonista para simbolizar sua luta, podem resgatar seu cadáver das profundezas lodosas da baía da Guanabara onde ele, para nós ainda permanece enquanto símbolo". Naquele momento, início da década de 1980, o apelo não teve grande ressonância entre estudiosas e militantes feministas. No entanto, não tão longe dali, nos anos 1990, uma biografia (Agostinho, Paula e Brandão, 1994) foi lançada procurando mapear sua trajetória de vida e arte. O livro não despertou grandes críticas ou polêmicas, provavelmente, devido ao seu caráter mais descritivo, apesar de conter importantes imagens de arquivo e depoimentos. A biografia é pouco crítica e segue o tom heróico e teleológico que vai da infância à morte como uma jovem/adulta rebelde. No entanto, o livro passou a ser uma importante referência nas muitas matérias de jornais e revistas que emergiram no cenário brasileiro por ocasião do centenário do seu nascimento, em 2017. Na matéria do jornal $O$ Globo $^{12}$, Luz del Fuego figura entre as vedetes mais conhecidas do país, nas palavras da jornalista (historiadora) Frima Santos:

Vedetes foram mulheres à frente de seu tempo. Feministas por essência. Mas Luz Del Fuego foi além: em um mundo pós-guerra e moralista, ela desafiou preconceitos, feminista de uma maneira quase intuitiva. Um dos seus feitos está ligado à aviação: ela foi uma das primeiras mulheres do país a receber um brevê para pilotar aviões ( $O$ Globo, 10/02/2017).

12 [https://acervo.oglobo.globo.com/em-destaque/luz-del-fuego-dancarina-atrizque-pioneira-do-nudismo-na-america-latina-20904612 - consulta em 10 maio 2019]. 
Não fica claro o que a autora entende por feminista quase intuitiva ou por feministas por essência, como se fosse um dado natural a conjugação entre ser artista popular (dançarinas, vedetes e cantoras) e ser feminista. Os pioneirismos na afronta individual (e no alto custo pago por isso) às convenções de gênero rigidamente estabelecidas para moças bem comportadas no pósguerra, como vestimentas, ofícios, afazeres, leituras e pensamentos são elencados como amostra de uma ação quase involuntária por parte destas mulheres cuja ousadia hoje celebramos e nomeamos de feminista. É muito provável que os significantes "intuitiva" $e$ "essência" foram mobilizados como elogio, no entanto, reforçam justamente o caráter ingênuo e despolitizado com o qual essas rebeldias são pensadas no âmbito mais geral das lutas políticas por transformações nos modos de subjetivação.

Outro estudo sobre Luz, afirma:

O comportamento rebelde, feminista e modernista de Luz eram manchetes constantes nos principais jornais da época. Embora tenha conquistado muitos admiradores, Dora era vista como uma ameaça à moral e aos bons costumes, conhecida por suas apresentações com cobras e totalmente nua o deputado Aldebaro Klatau, Belém, verberou suas exibições alegando que suas ações e trajes eram uma provocação aos lares cristãos e uma exploração da luxúria e depravação (Alves et al., 2016:46).

No argumento dos autores há uma forte correlação entre o histórico cenário político da família, as tramas políticas nas quais seu irmão senador está imerso e aquelas que estão sendo empreendidas por Luz, em seu acerto de contas com a família; principalmente o modo como foi tratada em sua juventude, quando sofreu assédios e fora severamente penalizada por isso. Como não é o caráter performativo do feminismo de Luz que está sendo discutido pelos autores, o artigo envereda para outra associação, aquela que ocorre entre a modernidade de Luz e o conservadorismo de sua família. 
Para mim, o jogo familiar interessa justamente porque, como alertou De Lauretis (1987:33-34) em sua crítica a muitas intelectuais feministas, não é possível encarar as tecnologias que produzem as desigualdades $e$ as atuações de gênero sem considerar o papel central que a família exerce, em especial, para pensarmos as violências de gênero, pois é bem ali, no seio da familia que muitas destas violências e constrangimentos são acionados como modo de naturalização dos respectivos comportamentos normativos. Dora teve que enfrentar toda a violência de sua família para se tornar Luz.

É também no seio da família que Luz enfrenta por duas vezes a internação psiquiátrica, lidando de perto com algo muito comum na década de $50^{13}$, que era de associar as desobediências, os descontentamentos e desregramentos dos humores $e$ comportamentos como características de doenças mentais passíveis de tratamento e/ou internação. Em outras palavras, a medicalização e patologização da rebeldia. Não sei bem como (essa história ainda está por ser contada), mas Luz conseguiu se desvencilhar destas violências psiquiátricas ${ }^{14} e$ familiares e criar seu próprio espaço. Transformou uma noção psiquiátrica $e$ midiática de rebeldia como negação inconsequente das regras sociais em uma subjetividade rebelde capaz de produzir um estilo de vida outro, ou seja, positivou e levou para outro patamar político a subjetividade rebelde.

Em 2017, na ocasião de seu centenário, uma revista capixaba exibe uma matéria de capa em homenagem a Luz, com

\footnotetext{
13 "Desafio, desregramento, desobediência, foram características traduzidas com muita facilidade para a linguagem da doença" [Defiance, unruliness, disobedience where characteristics they translated all too readily into the language of illness (Appignanesi, 2008:12)].

${ }^{14}$ Os horrores de um dos maiores hospitais psiquiátricos do Brasil, que funcionou em Barbacena, de 1903 até a década de 80, superlotado e protagonizou o extermínio de 60 mil pacientes, vítimas de falta de cuidados e maus-tratos variados, foram denunciados no livro de Daniela Arbex, Holocausto Brasileiro. Vida, genocídio e 60 mil mortes no maior hospício do Brasil (2013, São Paulo, Geração Editorial)
} 
a seguinte chamada: "A revolução do fogo - A famosa naturista capixaba Luz del Fuego, um dos ícones do movimento feminista brasileiro, completaria cem anos em fevereiro último". A imagem que segue ao lado da matéria, que encontra-se na matéria, sem créditos, é muito próxima a outra que se encontra no livro Verdade Nua, de autoria da própria Luz. ${ }^{15} \mathrm{Na}$ foto, o registro da intimidade entre Luz e a jiboia. O olhar dirigido para fora da câmera, sem confrontar o espectador, revela ao mesmo tempo serenidade e ausência de medo (tanto da cobra quanto do mundo que a cerca). Quem tentou quem nesta relação?

Figura 19: O beijo- Fonte: Verdade Nua (Fuego; 1948)

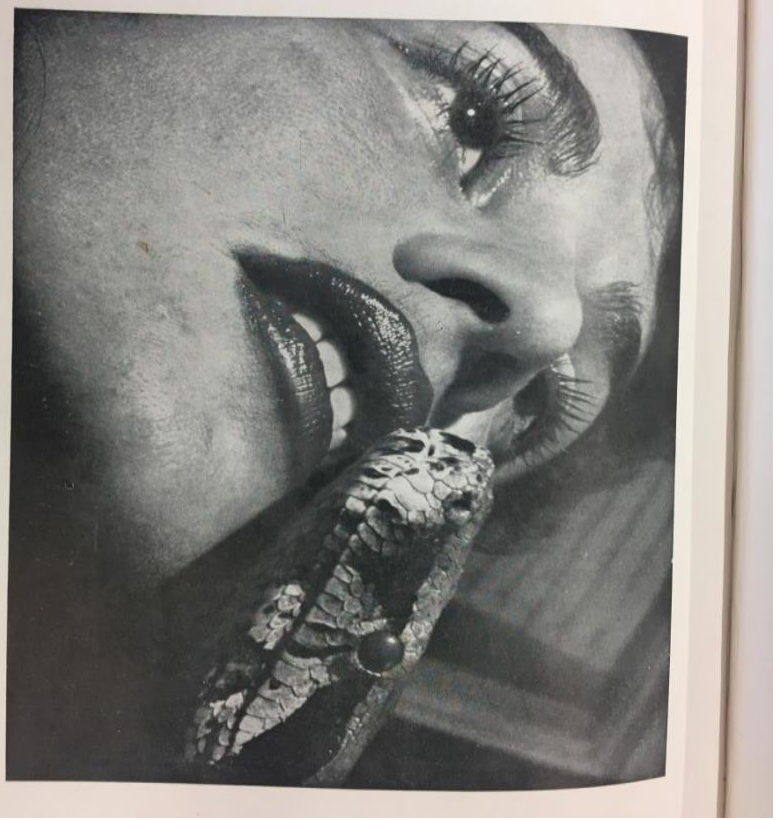

${ }^{15}$ Embora não controle seus usos, Luz participava ativamente da produção de suas imagens. De certo modo, corrobora o argumento de Anchieta (2019). 
O tom elogioso do artigo segue uma estética sensacionalista - tanto na escrita quanto no modo como recorta e sobrepõem texto e imagem. Enfim, todo o design da matéria potencializa o caráter de "celebridade" local da persona de Luz. No entanto, o texto pontua aspectos políticos atrelados à sua imagem.

A chamada afirma o caráter icônico do "feminismo" de Luz e a matéria justifica o seu caráter precursor:

Ela foi precursora do feminismo, do ambientalismo e do naturismo. Teve posição de vanguarda na época dela. A importância dela pode ser vista agora. Nenhuma outra vedete mereceu qualquer homenagem pelos cem anos do seu nascimento. O movimento político dela foi realçado pela sua postura $e$ isso mudou o sentimento de constrangimento de uma época, da família, para o orgulho, de hoje (Cadernos D., 2017:06).

Nos últimos cinco anos, justamente nesta primavera feminista, aumentaram as referências a Luz del Fuego destacando o caráter pioneiro da artista. Por isso, parece-me que chegou o momento de refletir um pouco mais sobre Luz de Fuego, personagem e mulher, bem como a relação entre nudez feminina $e$ feminismos.

Luz Del Fuego não teve na ocasião de sua vida e morte o apelo de ícone feminista como tiveram outras mulheres, tais como Pagu- Patrícia Galvão (militante, escritora, poeta), ou a irreverente Leila Diniz (atriz), ou ainda aquelas diretamente vinculadas à luta político-partidária como Berta Lutz, por exemplo. Seria a peja de louca - todos os escândalos que provocou ao longo de sua vida - o que a colocou em suspeição pelo ponto de vista de um feminismo conservador? Da vida de interior que vivenciou até por volta dos seus vinte anos, Dora transforma-se definitivamente em Luz, considerada pelo judiciário como praticante de "atentados ao pudor", justamente porque promoveu um estreitamento das fronteiras entre arte e vida.

Haveria conexão entre o sentimento de inadequação social, devido à sua constante defesa de um estilo de vida naturista e à 
centralidade do naturismo e liberdade sexual, um dos motivos pelo quais feministas que lhe eram contemporâneas, engajadas na construção de direitos políticos (sufrágio feminino, engajamento nas disputas partidárias, acesso a educação superior, ampliação do rol de profissões, etc.) e nos direitos sociais (luta pela liberdade de expressão, pelo divórcio, pelo aborto- direitos reprodutivos) não se solidarizaram e não partilharam de sua luta, que além destas frentes incluía uma outra ética de existência? Teria sido um "deslize" de Luz o fato de transformar o que era uma filosofia naturista, em um drama folhetinesco e, assim cair na tentação da espetacularização narcísica do corpo nu? Seria por aí que poderíamos entender as reticências e silêncios, quiçá um recalque do feminismo brasileiro com essa singular mulher?

Talvez sua "recuperação" ou reinserção no panteão das subversivas inspiradoras requeira um entendimento mais amplo das dinâmicas do desejo e das microrrevoluções que ajudou a criar. A noção de insurgência e insurreição postulada pela psicanalista Sueli Rolnik (2018) são fundamentais para alargar nossa compreensão. Rolnik faz uma distinção entre resistência (macropolítica) e insurreição (micropolítica). Estamos mais familiarizados com as resistências, em especial, as lutas feministas que confrontam as violências do Estado $e$ outras instituições (escola, família, religião, etc) sobre a vida das mulheres. No entanto, é necessário aderirmos às insurgências às políticas do desejo que nos limitam aos territórios normativos das subjetividades. Os agenciamentos estético-políticos mobilizados no $e$ através do corpo-vida de Luz, em seu entorno, nas muitas alianças que fez para se colocar num território criativo, tanto nos palcos quanto na ilha, a colocam no campo político das insurgências. No entanto, é importante entender que nem sempre as insurreições libertárias são necessariamente libertadoras. Parte das experiências de rupturas que Luz vivenciou com normas $e$ convenções do corpo, da sexualidade, da sociabilidade, foram constituídas em fricções constantes, resultando em alto grau de sofrimento e violência. Não há como, nem porque romantizar uma vida rebelde. 


\section{Luz por Luz}

O livro Verdade Nua (1948) é uma publicação um tanto caseira, não tem número de páginas, nem editora. A primeira edição praticamente foi confiscada pela polícia e por sua família. A segunda edição (1950) vendeu várias cópias usando a estratégia de envio pelo correio. Encontrei a primeira edição apenas em uma biblioteca $^{16}$, depois de procurá-lo por bom tempo em livrarias $e$ sebos. Nele, uma espécie de carta de intenções e de explicações são formuladas por tópicos e entrecortadas por um verdadeiro ensaio fotográfico que mais dialoga do que ilustra o seu argumento. Fica claro que ela se sente incompreendida, "Sou considerada pelos ignorantes, claro, como leviana, exibicionista $e$ criatura imoralíssima", e logo na abertura expõe sua filosofia $e$ modo de vida para além do seu exercício criativo nos palcos. Sobre os palcos, aliás, faz uma delicada reflexão sobre a dança em bailados, arte que para ela comunica mais com o grande público, justamente porque incorporam, na sua coreografia, danças crioulas e maracatus. As referências afro-brasileiras e indígenas em suas coreografias são fruto de estudos seus sobre estas culturas para pensar outro tipo de teatro popular. É neste momento que se volta para comentar também sua relação com as cobras e os animais em geral, ou seja, sua ecosofia. ${ }^{17}$ Demonstra ser uma conhecedora tanto das propostas estéticas quanto políticas do modernismo, embora não se reportasse a alguns nomes (em especial de mulheres) consagrados na época.

Ao longo do texto, Luz formula várias críticas ácidas $e$ diretas ao falso moralismo tanto da igreja (e líderes religiosos)

\footnotetext{
16 Biblioteca Brasiliana Guita e José Mindlin, USP. Sou grata à equipe da biblioteca que generosamente possibilitou tanto o acesso ao livro quanto às imagens que aqui trago dele.

${ }^{17}$ Ecosofia (Ecologia + Filosofia) noção formulada por Felix Guatarri (1990) que propõe o arranjo político entre as três ecologias: meio-ambiente, relações sociais e subjetividade humana. Luz não estava mais viva quando Guatarri formulou essa noção, mas penso que guarda proximidades com o que Luz defende em Verdade Nua.
} 
quanto dos que se dizem fiéis e tementes a Deus. Para ela, julgam a vida alheia por um ponto de vista moralista $e$ antiquado. Guarda uma ironia maior para os pudores hipócritas das mulheres que se dizem mais "puras", porque se cobrem com fantasias, enquanto ela se propõe a enfrentar a lascívia do vigilante olhar masculino $e$ a sua sexualidade a nu.

Qual a diferença entre as vossas havaianas de umbigo de fora $e$ as vossas baianas mirandescas e esta nudez luxuriante com que me apresento? Qual a diferença entre o ritmo das vossas danças e o ritmo do meu corpo nu? Qual a diferença entre os vossos cérebros excitados pela Champanha, pelo éter, pelo odor de mulheres e homens $e$ a realidade que exponho aos vossos olhos?

No término desta introdução aos seus leitores, segue uma primeira imagem que ocupa uma página inteira:

Figura 20- descaramento- Fonte: Verdade Nua (Fuego, 1948) 
A escolha do olhar desafiador, direto para a câmera, como abertura do criterioso ensaio fotográfico de sua nudez, nos faz pensar no que representa o rosto $e$ o seu respectivo "descaramento" enquanto um primeiro gesto da nudez.

Num belo ensaio sobre a nudez, Giorgio Agamben (2014:127) ressalta o primado do rosto na configuração expressiva em relação ao conjunto do corpo. Quando o assunto é nudez, "o rosto, tornando-se cúmplice da nudez, olhando em direção à objetiva ou piscando ao espectador, dá a ver uma ausência de segredo, exprime somente um dar-se a ver, uma pura exposição". $\mathrm{O}$ livro todo é um grande gesto de coragem.

Quando Luz menciona o naturismo e o nudismo posicionase criticamente em relação ao cristianismo, por se fechar para a verdade do corpo humano. Sua explicação para a incorporação das vestes na vida cultural é calcada no evolucionismo e não na retórica cristã da percepção do nu como pecado. A bailarina das cobras era bem familiarizada com os debates alemães e europeus sobre a questão do naturismo e assinala a violenta (apesar da inicial aproximação) perseguição de Hitler aos naturistas.

Em Verdade Nua, Luz deixa claras suas predileções estéticas e morais, demonstrando uma formação intelectual ampla e vária, passando pela literatura, pela sexologia e pelas artes de modo geral. Como sua ênfase é demonstrar que sua capacidade de pensar está para além da "esquisita" e "excêntrica" dançarina, como os jornais teimavam em julgá-la ${ }^{18}$, Luz utiliza-se de vários argumentos para elucidar sua filosofia de vida naturista como plenamente razoável, moderna, saudável, culta e internacional. O

${ }^{18} \mathrm{http}$ ://almanaque.folha.uol.com.br/ilustrada 18set1950.htm - nesta matéria do Jornal Folha da Tarde de 1950, sobre o acidente que acabou coma possibilidade de existência do Partido Naturista, pois o memorial que continha as 50.000 assinaturas a favor do partido foi inteiro queimado com a queda do avião, a chamada inicia-se com a seguinte frase: "A notoriedade de Luz Fuego, essa esquisita bailarina vestida com serpentes, começou - devem estar lembrados os leitores - precisamente no carnaval de 48, quando, arrostando as iras do prefeito do Rio de Janeiro, tentou entrar no fabuloso baile que a Prefeitura realizava no Teatro municipal vestindo os seus trajes costumeiros, ou seja, suas duas famosas cobras". (grifos meus) 
livro que se pretende autobiográfico aproxima-se mais de um dispositivo literário-político, no qual expõe sua filosofia de vida.

Essa narrativa e os enunciados de Luz que extrapolam o livro formam um contraste com o que se veiculava sobre mulheres no mercado editorial de revistas da época. Como mostra a pesquisa de Margareth Rago:

Defendendo um feminismo mais "conservador do que revolucionário", na medida em que reduziam o conteúdo da emancipação feminina para um melhor desempenho dos papéis tradicionalmente reservados à mulher, as revistas acabavam reatualizando as projeções masculinas que constituíram a subjetividade feminina como sentimental, fútil e retardada. Na série de artigos publicados por esta imprensa, as metáforas do anjo, das flores, das plantas e das águas calmas foram amplamente empregadas para definir a subjetividade feminina, cujo centro deveria girar em torno do lar. Remetendo a Vitor Hugo, enfatizavam: "A mulher é a humanidade vista pelo seu lado tranquilo; a mulher é o lar, é a casa, é o centro de todos os pensamentos suaves" (Rago, 1993:8).

Em sua casa, Luz promoveu exibições de documentários sobre naturismo aos poucos interessados na novidade. ${ }^{19}$. Em 1954, Luz faz outra tentativa importante de desfazer os malentendidos em relação à sua pessoa. Ela ajuda a produzir (não há muitos detalhes sobre a produção em si) o filme Luz del Fuego, A Nativa Solitária, dirigido por Francisco de Almeida Fleming e que faz parte do acervo do Arquivo Público do Estado do Espírito Santo (APEES), feito em $16 \mathrm{~mm}$.

${ }^{19}$ Não consegui levantar documentários produzidos nos anos 1940 e 1950 exibidos por Luz, mas os que tive acesso dão uma ideia do que estava em pauta, como a defesa das atividades nuas sob o sol, fonte de vitalidade e felicidade $e$ que contam a história de como o naturismo se espalhou na Europa: Daughter of the sun (1962) dirigido por Herschell Gordon Lewis and David Friedman; Hide out in the sun (1960), dirigido por Doris Wishman; Isle of Levant (1959), dirigido por Werner Kunz; Nackt und frei - Die Geschichte der Freikrperkultur (1999), dirigido por Gerhard Thiel. 
A estrutura narrativa do documentário segue o espírito do argumento traçado em seu livro. Dá a falsa impressão inicial de ser um discurso egóico voltado para sua autopromoção para, por fim, aproveitando-se do interesse do espectador na vedete, defende abertamente que seu modo de vida não é nem imoral e nem ilegal, simplesmente, como ela insistia em dizer: natural. No início da década de 1950, as suas fotos nuas fizeram com que o livro fosse visto como pornográfico, embora não aludissem diretamente à luxúria e ao prazer condenava-se o caráter explícito da exposição dos seios e dos pelos pubianos, capazes de despertar a imaginação erótica de seus leitores e estimular a devassidão. Parte significativa da sociedade era bastante tolerante às ideias de Luz, com incentivadores artistas, políticos (não necessariamente de esquerda) e autoridades, bem como parte da própria população que ia aos teatros prestigiar suas apresentações; algumas delas aderiram às práticas naturistas na ocasião.

Luz não previu (pouca gente o fez) que os ares liberalizantes do final da década de 1950 e do início dos anos 1960, fossem ser drasticamente contaminados por violências brutais aos direitos civis e às liberdades individuais, bem como às manifestações artísticas. Pouco a pouco, as pessoas amedrontadas afastaram-se da ilha e de Luz, isolando-a e, assim, fragilizando ainda mais sua capacidade de reação às investidas conservadoras que continuaram vindo tanto de sua família quanto das dificuldades materiais que passou a enfrentar com o resfriamento da ilha como lugar de cultura e práticas esportivas e naturistas. Sua morte como aludiu o jornal, foi tão violenta que assustou:

Seu corpo e de seu empregado só foram encontrados quase duas semanas após o crime, a 400 metros da Ilha do Sol, amarrados a pedras e manilhas, submersos na Baía de Guanabara, conforme $\mathrm{O}$ Globo noticiou na edição de $1^{\circ}$ de agosto de 1967. A morte violenta de Luz assustou o Rio de Janeiro, e o processo policial tomou as páginas dos jornais durante dias. Ela tinha trânsito livre entre políticos $e$ 
militares: todos temiam as possíveis revelações de seu bombástico diário, que desapareceu. ${ }^{20}$

O corpo nu, que no entendimento de Luz deveria ser natural, é efeito de um exercício de biopoder (Foucault, 1986), motiva toda uma política cultural pautada no controle do corpo $e$ da subjetividade. O domínio da nudez tem sido um modo de domesticar e moldar todo tipo de troca entre humanos (afetivas, sexuais, monetárias, éticas, sagradas), estabelecendo tempo/lugar, parâmetros de certo/errado, selvagem/civilizado, enfim, demarca as fronteiras e territorialidades que cercam os usos/abusos do corpo em sociedade ao longo da história. Além disso, ainda configura o campo de inteligibilidade dos modos de representálo. ${ }^{21}$ Por exemplo, todos os debates que perpassam as questões jurídicas em torno do nu artístico e dos possíveis lugares e modos nos quais o nu pode estar representado e ser exibido em público; além de toda uma história das relações entre corpo, nudez e pornografia, estabelecendo ao mesmo tempo uma relação entre liberdades $e$ autonomia corporais $e$ irreverências $e$ insurgências políticas frente às tentativas de controle social mais geral (Hunt, 1999).

Embora os estudos histórico-culturais apontem na direção de que não há nada de natural no corpo nu, nem tão pouco a nudez seja portadora de uma verdade primária à qual poderíamos nos apegar; o naturismo foi um importante movimento de revisão das relações simbólicas com o corpo nu. Influenciou toda uma geração hippie que redimensionou as liberdades do corpo e da sexualidade livre e agregou aos princípios do naturismo outras

\footnotetext{
20 https://acervo.oglobo.globo.com/em-destaque/luz-del-fuego-dancarina-atrizque-pioneira-do-nudismo-na-america-latina-20904612\#ixzz6AalJ71vZ

${ }^{21}$ Há uma vasta e importante literatura que trata da historicidade do corpo e das suas relações com a medicina, a arte, o jurídico; bem como a história da nudez e das várias questões éticas e estéticas que a cercam, desde uma história da censura, até uma história da pornografia. Para uma visão mais geral destas questões, sugiro: Batista (2011), Vigarello (2016), Marie Del Priori (2011); Sant'anna (2014), Baubérot (2004).
} 
críticas culturais, tais como a centralidade da razão e da consciência, contrapondo experiências de modificação dos estados mentais através dos usos de drogas ${ }^{22}$.

Apesar de não ser original, a defesa que Luz fez do nudismo teve um viés libertário talvez maior do que o naturismo (nem todo naturismo pratica ou defende o nudismo) por duas razões importantes de serem destacadas: primeiro, por se tratar de ser uma mulher à frente desta bandeira. Na Europa e no Brasil do início do século a visibilidade do nudismo e do naturismo se deu fortemente via pensadores e ativistas homens; em segundo, por aliar ao nudismo uma plataforma política mais ampla de defesa da emancipação feminina, vista a partir de três lutas fundamentais: a educação sexual, a maternidade como escolha e não destino, e o divórcio. Embora Luz estivesse imbuída de um naturalismo romântico, entendia muito bem os funcionamentos das lutas político-partidárias $^{23}$. Todas as estratégias políticas, retóricas, visuais, narrativas (os livros), teatrais (seu trabalho como atriz e vedete), que produziu ao longo de sua vida conformam um imenso legado. Inspirada em Lauretis, denomino este legado de tecnologias anticoloniais de gênero, na medida em que desestabilizam as desigualdades e hierarquias de gênero, de um ponto de vista de uma artista $e$ intelectual, lida como branca $e$ filha de família abastada, mas profundamente marcada pelas culturas negras e indígenas, que deu ao naturismo e nudismo europeus um acento amefricano ${ }^{24}$ (Gonzales, 1988).

22 Uma história dessa relação entre naturismo e movimento hippie pode ser encontrada em Philip Carr-Gomm (2010).

23 http://memoria.bn.br/DocReader/221961 03/2226 (acesso ao jornal pela página da Hemeroteca da Biblioteca Nacional). Outra Matéria traz em pleno jornal uma foto de uma das mulheres que estavam com Luz no primeiro campo de nudismo organizado por ela nas proximidades de sua residência no Rio de Janeiro. http://memoria.bn.br/DocReader/221961 03/7406

${ }^{24}$ Tomo a liberdade de usar o sofisticado aporte epistemológico elaborado por Gonzales, focado no triângulo- racismo, colonialismo, imperialismo e seus efeitos, sabedora de que Luz não é negra, nem mobilizou repertório antirracista, mas é notável que sua dimensão do ser mulher brasileira represente uma conjugação inescapável com os legados africanos e indígenas inferiorizados pelo colonialismo 


\section{Concluindo - as luzes de Luz Del Fuego em nós}

A Luz Del Fuego de Dora Vivácqua (1917-1967), de Rita Lee (na canção de 1975), de Lucélia Santos (filme de 1982), Elisa Romero e Rita Cadillac (na peça teatral de 2018), de Cristina Azevedo (1997), e dos roteiristas, diretores e poucos escritores e intelectuais que produziram e escreveram sobre Luz ao longo das últimas cinco décadas desde sua morte (mencionados ao longo do texto, entre outros), apontam para o importante legado político e a força das lutas representacionais da época em que viveu e do tempo que vem até nós. Embora focados na persona de Luz del Fuego, iluminam os arredores das disputas político-ideológicas fundamentais para entendermos o esgarçamento entre conquistas pessoais e transformações profundas nos modos de subjetivação de muitas gerações, que se entrelaçam por temporalidades nada lineares. Luz não é excepcional, tampouco comum.

A escuta atenta destas muitas vozes e de outras que virão é um exercício crítico necessário, não na busca da verdade nua não sabemos em que medida Luz é uma invenção de Dora, de David, dos jornalistas, das feministas, minha -, mas de esforço de entendimento e de um mínimo de reconhecimento de como o inconsciente estético ${ }^{25}$ opera no modo como significamos nosso passado $e$ nosso agora, no intervalo que conecta fantasia $e$ realidade. Em outras palavras, fazer das muitas narrativas de uma vida uma forma de testemunha (como a arte e a poesia) "em favor da racionalidade profunda da fantasia" (Rancière, 2009:47).

de gênero, do modo como ela foi capaz de traduzi-lo em vida e arte. Para um maior entendimento do alcance do pensamento de L. Gonzalez, ver Cardoso (2016).

${ }^{25}$ Sobre as complicadas relações entre o inconsciente e o estético, Rancière (2011:56) chama atenção para: "Que a história seja real ou fictícia, pouco importa. O essencial é que ela seja unívoca, que oponha à indiscernibilidade romântica e reversível do imaginário e do real uma disposição aristotélica de ações e saberes direcionada para o acontecimento maior de um reconhecimento" (grifos meus). 
Luz não nasceu periférica, sua posição periférica, sua ecopolítica beligerante e sua subjetividade rebelde devem-se aos caminhos que tomou ao situar-se numa posição de confronto à moral $e$ aos bons costumes dos cidadãos de bem brasileiros (e ser presa várias vezes por isso).. Por sua luta pela liberação do corpo e da sexualidade feminina, ao questionar o nu como vergonha, o sexo como pecado e a obediência das mulheres como submissão; podemos entender que no conjunto de suas ações de domínio público, sua questão de fundo foi de um tipo raro, pois sua persistente rebeldia insistia em nos libertar a todos da injunção do sexo como definidor de nossa identidade e personalidade. Com relação à sexualidade (casta, pudica, maternal) reservada às mulheres, Luz parece nos incitar a pensar não em libertar a sexualidade, mas da sexualidade enquanto dispositivo que molda nossa vida (Foucault, 2009). Em um momento como o atual, de cultivo do ódio ${ }^{26}$ e de políticas públicas explicitamente antifeministas, repensar o modo como representamos e exibimos mulheres feministas do passado é fundamental (Richard, 2002; Rancière, 2011). Fundamental ainda é nossa atenção acadêmica e cidadã em relação às experiências e vidas artísticas rebeldes, e a politização do nosso olhar em relação às mesmas.

\section{Filmografia:}

A NATIVA SOLITÁRIA. Dirigido por Francisco de Almeida Fleming. Curta metragem. Rio de Janeiro: América Films, 1954. 30min

LUZ DEL FUEGO. Dirigido por David Neves. Rio de Janeiro: Embrafilme. 1982. 106min.

\footnotetext{
${ }^{26}$ As atuais as reflexões de Peter Gay (1995:11), em cuja introdução do vol.III a primeira frase anuncia: "As cicatrizes que a agressão deixou no rosto do passado são indeléveis", e nos convida a olhar com destreza para o ódio (de classe, entre etnias, religiões, nações, etc.) como um dos intensos e mais presentes motores das grandes transformações históricas. Para adentrar nas questões históricas que tratei ao longo deste artigo sobre luz, indico a quarta parte do livro, dedicada à "O poderoso sexo frágil".
} 


\section{Referências bibliográficas}

ADORNO, T. W. Teoria Estética. Lisboa, Edições 70, 1970.

AGOSTINHO, Cristina, PAULA, Branca de, BRANDÃO, Maria do Carmo. Luz del Fuego: A Bailarina do povo. São Paulo, Best Seller, 1994.

ALVES et al. Luz Del Fuego: História, Poder e Política. Revista Historiador, número 8, ano 8., fevereiro de 2016 [http://www.historialivre.com/revistahistoriador].

ANCHIETA, Andrea. Imagens da Mulher no Ocidente Moderno. Vol. I. São Paulo, EDUSP, 2019.

BATISTA, Stephanie Dahn. O corpo falante: as inscrições discursivas do corpo na pintura acadêmica brasileira do Século XIX. Tese de Doutorado, UFPR, 2011.

BAUBÉROT, Arnaud. Histoire du naturisme: le mythe du retour à la nature. Rennes: Universitaires de Rennes, 2004.

BIDASECA, Karina. Estéticas descoloniales, cuerpos, tiempo y espacio: lós selknam de tierra Del fuego y lãs siluetas de Ana mendieta. In: ROCHA, M. (org.). Gênero, Cultura e Midia. Fortaleza: Expressao Gráfica e Editora, 2016.

CANEVACCI, M. Fetichismos Visuais - Corpos Erópticos e Metrópole Comunicacional. São Paulo: Atelie, 2009.

CARDOSO, Cláudia Pons. Amefricanizando o feminismo: o pensamento de Lélia Gonzalez. Rev. Estud. Fem., vol. 22, n. 3, Florianópolis, Dec. 2014,

pp.965-986

[http://www.scielo.br/scielo.php?script=sci_arttext\&pid $=$ S0104-

026X2014000300015\&lng=en\&nrm=iso - acesso em 13 nov. 2020. https://doi.org/10.1590/S0104-026X2014000300015.

CARR-GOMM, P. A Brief History of Nakedness. London, Reaktion Books, 2010.

DEL PRIORE, Mary. Histórias íntimas: sexualidade e erotismo na história do Brasil. São Paulo, Planeta do Brasil, 2011.

DESJARDINS, Mary. Star Studies. Feminist Media Histories 4(2), 1 April 2018, pp.185-190. DOI: https://doi.org/10.1525/fmh.2018.4.2.185 
FOUCAULT. M. A Microfisica do Poder. Rio de Janeiro, Graal, 2009.

GAY, P. O Cultivo do Ódio. São Paulo, Cia. Das Letras, 1995.

GONZALEZ, Lélia. A categoria político-cultural de amefricanidade. Tempo Brasileiro, n. 92/93, Rio de Janeiro, pp.69-82, jan./jun. 1988

GUATTARI, Félix. As três ecologias. Campinas, Papirus, 1990 [Tradução Maria Cristina F. Bittencourt].

HOFFMAN, Brian. Naked: a cultural history of American Nudism. New York: New York University, 2015.

HUNT, L. (org) A invenção da Pornografia: Obscenidade e Origens da Modernidade 1500-1800. São Paulo, Hedra, 1999 [Trad.Carlos Szlak].

KRZYWINSKA, Tanya. Sex and the cinema. London, Wallflower Press., 2006.

LAURETIS, T. Technologies of Gender. Indianapolis, Indiana University Press, 1987.

MAYNE, J. The Woman at the Keyhole. Feminism and Women's Cinema. Indianapolis, Indiana University Press, 1990.

MENEZES, Thiago de. A verdadeira luz Del Fuego. $2^{\text {a }}$ ed. São Paulo, All Print Editora, 2012.

MENEZES, Thiago. A verdadeira Luz del Fuego. São Paulo, All Print Editora, 2011.

PINTO, Pedro Plaza. Paulo Emílio e a emergência do Cinema Novo: débito, prudência e desajuste no diálogo com Glauber Rocha e David Neves. Tese de doutorado, ECA - USP, 2008.

RAGO, M. Imagens da prostituição na belle époque paulistana. cadernos pagu 1993, pp.31-44 [https://periodicos.sbu.unicamp.br/ojs/index.php/cadpagu/article/view/ 1679].

RANCIÈRE, J. O Inconsciente Estético. São Paulo, Editora 34, 2009.

RANCIÈRE, J. Staging the People: The Proletarian and his double. London, Verso, 2011. 
RICHARD, Nelly. Intervenções Críticas. Arte, Cultura, Gênero e Política. Belo Horizonte, Editora UFMG, 2002.

ROLNIK, S. Esferas da Insurreição. Notas para uma vida não cafetinada. São Paulo, N-1 edições, 2018.

SANT'ANNA. D. B. História da Beleza no Brasil. São Paulo, Editora Contexto, 2014.

SILVA, A. \& CARVALHO, Joaquim. Luz Del Fuego. Rio de Janeiro, Codecri, Morena Produtores de Arte, 1982.

VIGARELLO, G. Sentimento de si: História da percepção do corpo Séculos XVI-XX. Rio de Janeiro, Vozes, 2016.

WILLIAMS, L. Screening Sex. London, Duke University Press, 2008. 